Review

\title{
Vanadium: Biological, Environmental, and Engineering Aspects
}

Dieter Rehder ${ }^{*}$

Department of Chemistry, University of Hamburg, D-20146, Hamburg, Germany; E-Mail: rehder@chemie.uni-hamburg.de

* Correspondence: Dieter Rehder; E-Mail: rehder@chemie.uni-hamburg.de

Academic Editor: Maxim L. Kuznetsov

Special Issue: Coordination Chemistry and Metal Complexes

Advances in Chemical Research

2020, volume 2 , issue 1

doi:10.21926/acr.2001002
Received: December 18, 2019

Accepted: December 31, 2019

Published: January 8, 2020

\begin{abstract}
Vanadium is an element that is widely distributed in Earth's crust as well as in sea-water and ground-water reservoirs. Therefore, it exerts a great influence on the issues related to life and environment. Vanadium is utilized by several marine organisms. For example, there are vanadate-dependent haloperoxidases in algae and several bacteria, e.g., Azotobacter, use it for nitrogen fixation and bacterial reduction involves the conversion of vanadate to oxidovanadium (IV). The similarity between vanadate and phosphate imparts a physiological functional role to vanadate (V), and consequently, several aspects of medicinal potential to vanadate and vanadium coordination compounds, such as their use in the treatment of diabetes, cancer, and cardiovascular problems, which may be explained in conjunction with vanadate/phosphate antagonism. Similar considerations apply to the efficacy of vanadium compounds in the treatment of HIV and [tropical] diseases caused by bacteria and protozoa. In addition to this biological efficacy, vanadium plays an increasingly recognized role in industrial processes, such as steel production, oxidation catalysis, and vanadium-based energy storage (batteries) and solar cells.
\end{abstract}

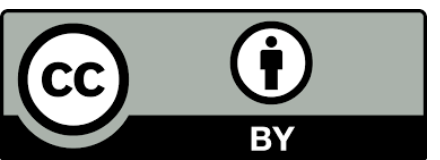

(C) 2019 by the author. This is an open access article distributed under the conditions of the Creative Commons by Attribution License, which permits unrestricted use, distribution, and reproduction in any medium or format, provided the original work is correctly cited. 


\section{Keywords}

Vanadate; environmental significance; haloperoxidases; nitrogenase; diabetes; tropical diseases; bacterial deployment; industrial use; batteries

\section{Introduction}

With an overall abundance of $0.019 \%$, vanadium is the $22^{\text {nd }}$ most abundant element in Earth's crust, where it exists in the form of seventy minerals, and in the oxidation states of +III, +IV, and $+V$. This element is also present in shales and crude oil, for example, in the form of oxidovanadium (IV) porphyrins or bound to the thiophenogenic compounds. In seawater [1a], vanadate (essentially, $\mathrm{H}_{2} \mathrm{VO}_{4}{ }^{-}$) is present at an average molarity of $30 \mathrm{nM}$ (next to molybdate, the second most abundant metal in seawater), and serves as a partially essential energy source for marine organisms, such as macroalgae (seaweeds), sea squirts, and fan worms. Moreover, the utilization of vanadate in the conversion of halide to hypohalous acid by, inter alia, seaweeds (such as Ascophyllum), and the concomitant release of the halide species and/or singlet oxygen into the atmosphere, generate consequences for the atmospheric chemistry. In certain mineral water springs, vanadium concentrations may reach a value of $50 \mu \mathrm{M}$, while the mean vanadate concentrations in freshwater are much lower [1b]. The global omnipresence of vanadium [1c] accounts for its generally non-specific presence in living organisms as well. A few on-shore organisms, such as certain lichens and the mushrooms belonging to genus Amanita, contain a functionally active vanadium compound named amavadin. Several bacterial species exploit the redox equilibrium between $\mathrm{V}^{\mathrm{V}}$ (commonly in the form of $\mathrm{H}_{2} \mathrm{VO}_{4}{ }^{-}$or $\mathrm{VO}^{3+}$ ) and $\mathrm{V}^{\mathrm{IV}}$ (as $\mathrm{VO}^{2+}$ ). It is noteworthy in the context of bacterial activity that vanadium nitrogenase in Azotobacter is responsible for the conversion of aerial $\mathrm{N}_{2}$ into $\mathrm{NH}_{4}{ }^{+}$. Whether vanadium is essential for humans [and other mammals], in low concentrations, as an antagonist and consequently as the regulator for the phosphatases, has not yet been assessed conclusively. In this context, vanadium compounds have attracted considerable attention regarding their potential medicinal applications [2a]. Besides the afore-stated biological functions, vanadium has been used traditionally as an additive in steel (ferro-vanadium), as an oxidation catalyst $\left(\mathrm{V}_{2} \mathrm{O}_{5}\right.$ in the production of sulfuric acid), and more recently, in the production of high-capacity flow batteries which are based on lithium vanadate. Recently, a few reviews on the role of vanadium in natural as well as in medicinal and industrial processes have been published in the literature [2b, c-4].

\section{Biological Aspects}

In this section, the following aspects would be addressed: the role of vanadium (a) in enzymes (haloperoxidases, nitrogenases), (b) the role of vanadium in ascidians and fan worms, (c) microbial use of vanadium and its transformation, (d) its physiological aspects (the phosphate/vanadate antagonism), including potential medicinal applications. Several reviews concerning these aspects have been published previously [5-7]. 


\subsection{Vanadium-Dependent Enzymes}

Vanadate-dependent haloperoxidase (VHPO) enzymes have been isolated from marine algae (in particular, Ascophyllum nodosum; Figure 1, right) and from hyphomycetes fungi such as the mold Curvularia inaequalis; these enzymes may also be present in certain cyanobacteria [7]. Haloperoxidases catalyze the two-electron oxidation of halides (iodide and bromide in particular, although chloride and pseudohalides such as thiocyanate may also serve as substrates for this reaction) to hypohalous acids or hypohalites, in the presence of a peroxide (hydrogen peroxide), as depicted in Figure 1 and eq. (1a) regarding the formation of hypobromous acid/hypobromite. These hypohalites are strong oxidizing agents which are probably involved in the protective antiparasitic mechanisms in algae. The hypohalous acids HOX may further produce, in a symproportionation reaction, free halogens $X_{2}$ [eq. (1b)], which when released in the air, undergo photolytic splitting to form halogen radicals. These halogen radicals, in turn, contribute to the annihilation of the ozone layer [eq. (1c)]. Therefore, a climatological impact should be considered in the areas with excessive algal bloom due to over-fertilization [5].
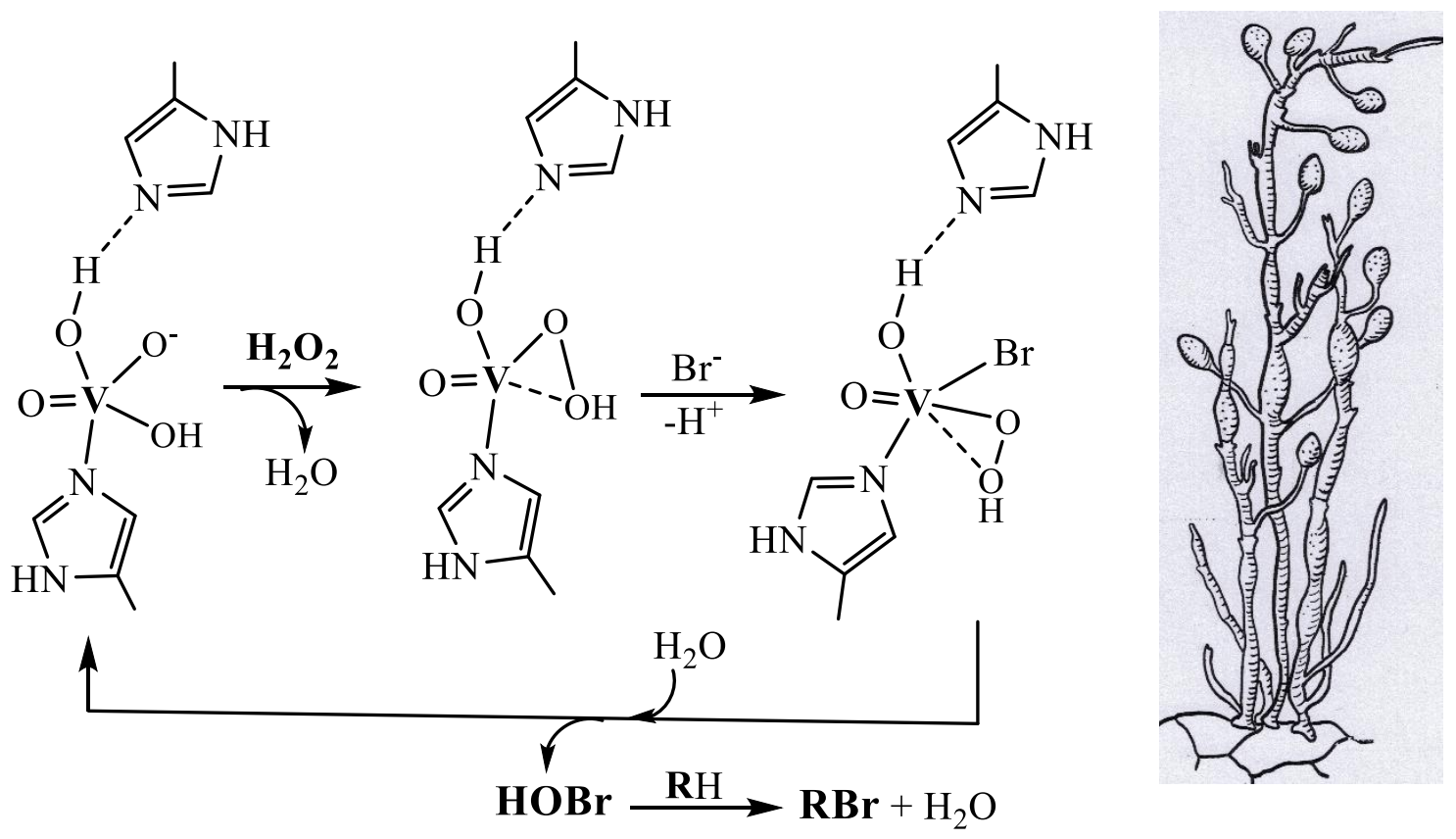

Figure 1 Left: The conceivable mechanism for the formation of hypohalous acid (shown here for $\mathrm{HOBr}$ ) at the active center of a bromoperoxidase, based on an earlier report [8]. Right: The marine brown alga Ascophyllum nodosum is the "pioneer" in the establishment of the biological function of vanadium as the central and active constituent of vanadate-dependent bromoperoxidases [9].

$$
\begin{aligned}
& \mathrm{Br}_{2}+\mathrm{H}_{2} \mathrm{O}_{2} \rightarrow 2 \mathrm{HOBr} \\
& \mathrm{HOBr}+\mathrm{Br}^{-}+\mathrm{H}^{+} \rightarrow \mathrm{Br}_{2}+\mathrm{H}_{2} \mathrm{O} ; \mathrm{Br}_{2}+\mathrm{hnu} \rightarrow 2 \mathrm{Br}^{\circ} \\
& \mathrm{Br}+\mathrm{O}_{3} \rightarrow \mathrm{BrO}+\mathrm{O}_{2}
\end{aligned}
$$

The second enzyme of substantial importance in regard to life is a nitrogenase containing vanadium in its active center in place of the more commonly present molybdenum (Mo). 
Vanadium-dependent nitrogenase (VNase) has been isolated from the nitrogen-fixing $\left[\mathrm{N}_{2} \rightarrow \rightarrow\right.$ $\mathrm{NH}_{4}^{+}$; eq. (2)] aerobic bacterium Azotobacter vinelandii [10], and in times of Mo deficiency, from the bacteria that would otherwise employ molybdenum, for example, Rhodobacter capsulatus. Several other bacterial strains and cyanobacterial symbionts belonging to the family Nostocaceae also exhibit the presence of a vanadium-dependent nitrogenase. The ammonium ions formed as a result of the action of nitrogenase are subsequently employed in the biosynthesis of amino acids, and consequently, proteins. In its resting state, VNase has a $\left\{\mathrm{VFe}_{7} \mathrm{~S}_{9}\right\}$ cluster at its center, which is linked to the protein through cysteine, histidine, and homocitrate (the latter two are directly coordinate-bonded to vanadium). In contrast to the molybdenum analog of the enzyme, VNase is able to effectively reduce carbon monoxide and carbon dioxide to hydrocarbons [eq. (3) and (4)] [11]. VNase is also involved in the catalytic reduction of ethene to ethane [eq. (5)]. Furthermore, $\mathrm{HCN}$ may be subjected to enzymatically driven reduction reaction [12]; for example, in the reaction represented by eq. (6). A recently reported structure for the active center of the ironvanadium cofactor [containing, in its turn-over state, a $\left\{\mathrm{VFe}_{7} \mathrm{~S}_{8} \mathrm{OH}\right\}$ core] is depicted in Figure 2.

$$
\begin{aligned}
& \mathrm{N}_{2}+14 \mathrm{H}^{+}+12 \mathrm{e}^{-} \rightarrow 2 \mathrm{NH}_{4}^{+}+3 \mathrm{H}_{2} \\
& 2 \mathrm{CO}+10 \mathrm{H}^{+}+10 \mathrm{e}^{-} \rightarrow \mathrm{C}_{2} \mathrm{H}_{6}+2 \mathrm{H}_{2} \mathrm{O} \\
& \mathrm{CO}_{2}+\mathrm{H}^{+}+\mathrm{e}^{-} \rightarrow \rightarrow \mathrm{C}_{n} \mathrm{H}_{2 \mathrm{n}+2}\left(+\mathrm{H}_{2} \mathrm{O}\right) \\
& \mathrm{C}_{2} \mathrm{H}_{4}+2 \mathrm{H}^{+}+2 \mathrm{e}^{-} \rightarrow \mathrm{C}_{2} \mathrm{H}_{6} \\
& \mathrm{HCN}+4 \mathrm{H}^{+}+4 \mathrm{e}^{-} \rightarrow \mathrm{CH}_{3} \mathrm{NH}_{2}
\end{aligned}
$$

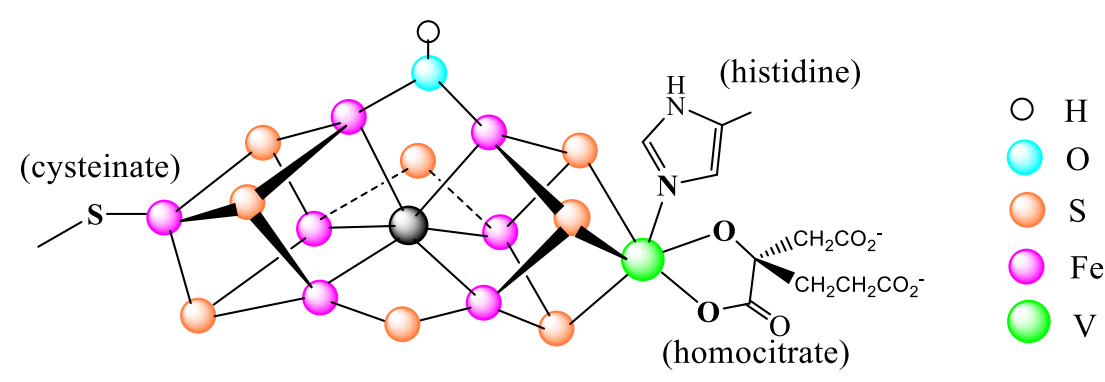

Figure 2 The cofactor of vanadium nitrogenase in its turnover state, according to the earlier work [13]. The light atom ligand (in blue) is represented here by $\mathrm{OH}$; this group is in hydrogen bonding contact with histidine and glutamine from the protein matrix.

\subsection{Vanadium in Ascidians and Fan Worms}

The marine organisms that utilize vanadium are the ascidians and the polychaete fan worms, although the use of vanadium and its potential benefit for these organisms has not been reported with valid evidence so far. Since the environmental occurrence of vanadium in the form of hydrogenvanadate (V) and oxidovanadium (IV) and (V) is toxic to a certain extent, the accumulation of vanadium by certain organisms may reflect its use as an anti-predator agent. Polychaeta fan worms uptake vanadium in the branchial crown, and it has been proposed by previous studies that $\mathrm{VO}^{2+}$ is bound by, and consequently suppresses, a nucleoside diphosphate kinase [14], which is consistent with the otherwise well-established fact that vanadate and/or 
oxidovanadium (IV) interact with, and thereby regulate, the phosphatases and kinases [see also, Section 2 (d)]. Ascidians (sea squirts) uptake vanadium in the form of vanadate (V) $\mathrm{H}_{2} \mathrm{VO}_{4}{ }^{-}$, which is subsequently reduced to $\mathrm{VO}^{2+}$ in two successive steps, and finally to vanadium (III) after binding to the lysine residues of vanabin (a vanadium-binding metallo-protein); the reaction is represented by eq. (7) [15a]. The reductant in the second step is cysteinylmethionine (CysMet). Interestingly, bacterium Pseudomonas isanchencovi, which was originally isolated from the tunicates, is also capable of reducing vanadate (V) to oxidovanadium (IV) [Section 2 (c)] and vanadium (III) [15b]. Vanadium accumulation in ascidians results in the activation of glucose-6phosphate dehydrogenase, an enzyme that catalyzes the interconversion between $D$-glucose-6phosphate and 6-phospho-D-glucono-1,5-lactone [eq. (8)]. The degree of vanadium accumulation in ascidians may reach up to $10^{7}$-fold the vanadate concentration in the seawater. The uptake of vanadate also occurs in several bacterial strains [16], as would be described in the section ahead.

$$
\begin{array}{lc}
\mathrm{NADPH} & \text { CysMet } \\
\mathrm{HVO}_{4}{ }^{2-} \rightarrow \rightarrow \mathrm{VO}^{2+}(\text { Lys }) & \rightarrow \rightarrow \mathrm{V}^{3+}
\end{array}
$$
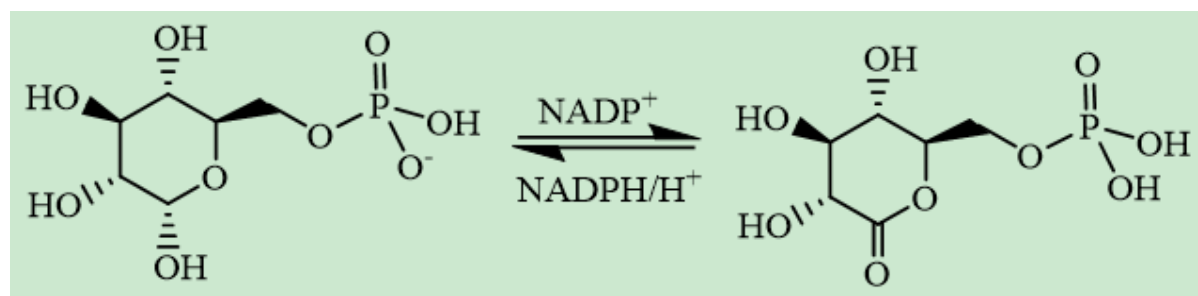

\subsection{Microbial Usage of Vanadium}

In this section, the utilization of inorganic vanadium by bacteria, predominantly in the redox processes, would be briefly addressed. The relevance of vanadium as a vital constituent of the nitrogenase enzyme in nitrogen-fixing bacteria, such as Azotobacter, has already been described in section 2 (a), and the bacterium potentially relevant for the reduction of vanadate in fan worm has been stated in section 2 (b), while the role of vanadium in the potential treatment of diseases of bacterial origin would be described in section 2 (d).

Certain bacteria which thrive in the soil, groundwater reservoirs, and wells, a group usually confined to the colloids, may use vanadium, generally in the form of dihydrogenvanadate (1-), as an energizer, through the redox conversion of vanadium (V) (commonly $\mathrm{H}_{2} \mathrm{VO}_{4}{ }^{-}$) and vanadium (IV) (usually in the form of $\mathrm{VO}^{2+}$ ) [17]. Such a process is of relevance in the context of detoxification of the industrial waste (waters) in conjunction with, for example, the production of vanadium-steel and sulfuric acid (in the presence of $\mathrm{V}_{2} \mathrm{O}_{5}$ as a catalyst). Well-investigated scenarios of bacterial vanadate reduction (and therefore, detoxification of vanadate) have suggested the presence of a periplasmic reductase as an initiator. Such vanadate reduction is conducted by, inter alia, the widely distributed dissimilatory metal-reducing bacteria Shewanella oneidensis and Shewanella loihica, belonging to the group of facultative anaerobic proteobacteria $[18,19,20]$. Formic acid, lactate, and/or citrate are employed as electron sources [see eq. (9)] for the oxidation of formic acid. The reduction product is $\mathrm{VO}^{2+}$, which is responsible for the blue coloration in the reaction medium, or the insoluble $\mathrm{VO}(\mathrm{OH})_{2}$, which essentially remains attached to the cellular surface. 


$$
2 \mathrm{H}_{2} \mathrm{VO}_{4}^{-}+2 \mathrm{H}^{+}+\mathrm{HCOOH} \rightarrow 2 \mathrm{VO}(\mathrm{OH})_{2}+\mathrm{CO}_{2}
$$

In addition to Shewanella, the soil bacterium Geobacter metallireducens, which is present in the subsurface soil, is able to effectively convert vanadate into oxidovanadium (IV), usually by employing acetate as the electron source [21]. Alternatively, lactate may serve as an efficient electron donor. A simplified scheme for the trans-membrane transport of the reduction equivalents (electrons) to the extracellular space and the bioavailability of the reducing equivalents for the reduction of soluble vanadate (V) to insoluble oxidovanadium (IV) are illustrated in Figure 3. The primary electron donor is lactate, which is located in the inner membrane and oxidized under the catalysis of lactate dehydrogenase to form pyruvate. The electrons are subsequently transferred across the periplasm by the cytochrome-c type hemoproteins CymA and MetrC through a changeover between the ferric and ferrous oxidation states of the central iron ion, and are delivered across the outer membrane to the extracellular space, where the reduction of soluble vanadate to insoluble oxidovanadium (IV) hydroxide finally occurs.

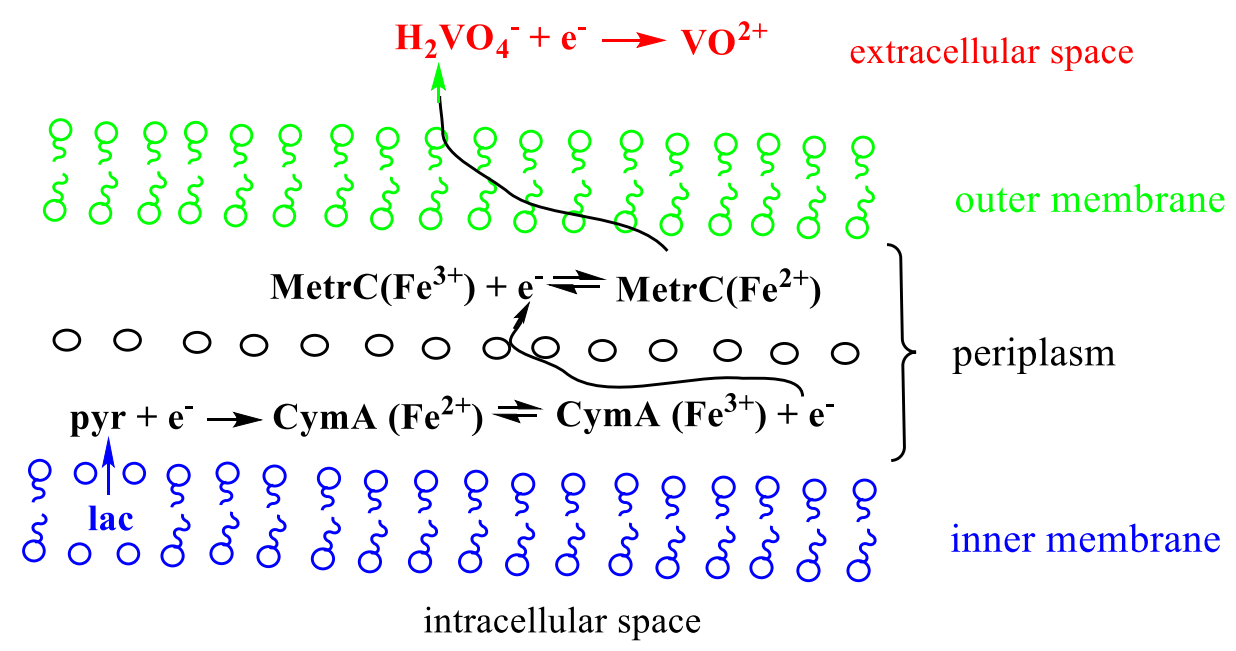

Figure 3 Electron transfer pathway (simplified) across a bacterial cell membrane, following earlier reports [22] and [23].

Geobacter metallireducens is capable of converting $\mathrm{V}^{\mathrm{V}}$ into $\mathrm{V}^{\mathrm{IV}}$ in concentrations of up to $5 \mathrm{mM}$ [24]. The bioreduction of vanadate in contaminated groundwater is conducted efficiently by using autohydrogenotrophic bacteria such as Clostridium and Rhodocyclus [25] [eq. (10)]. These bacteria deliver the reduction equivalents (electrons) to vanadate by employing molecular hydrogen $\left(\mathrm{H}_{2} \rightarrow\right.$ $\left.2 \mathrm{H}^{+}+2 \mathrm{e}^{-}\right)$.

$$
\mathrm{H}_{2} \mathrm{VO}_{4}^{-}+2 \mathrm{H}^{+}+\mathrm{e}^{-} \rightarrow \mathrm{VO}(\mathrm{OH})_{2}+\mathrm{H}_{2} \mathrm{O}
$$

\subsection{Vanadium and Human Physiology; Medicinal Applications}

The average daily intake of vanadium in humans is about $2 \mathrm{mg}$. The intake is essentially in the form of vanadate $\mathrm{H}_{2} \mathrm{VO}_{4}{ }^{-}$present in the water, oxidovanadium (V) and (IV) present in nutrients, and $\mathrm{V}_{2} \mathrm{O}_{5}$ in the air available for breathing. This amount of ingested vanadium is clearly below the tolerable level of $10 \mathrm{mg}$. Vanadium ingested via water and food may be resorbed in the form of 
vanadate, which enters the blood circulation. However, most of this vanadium is generally converted to $\mathrm{VO}(\mathrm{OH})_{2}$ in the gastro-intestinal trail, and finally removed from the body along with the feces. Inhaled vanadium compounds, such as vanadium oxides in the industrial or the otherwise polluted areas, enter the bloodstream, where they are converted to $\mathrm{H}_{2} \mathrm{VO}_{4}{ }^{-}$in case of vanadium $(\mathrm{V})$ or in case of $\mathrm{VO}^{2+}$, are bound to the iron sites of transferrin [26a], and to a lesser extent, also to serum albumin. The transferrin complex may enter the cells and release the oxidovanadium ion, which then becomes involved, at least in part, in various secondary reactions with different intracellular compounds. In the form of vanadate, vanadium may enter the cells through the phosphate channels. Specific vanadium coordination compounds which have been either introduced intravenously or generated in the blood serum from vanadate and the serum constituents (such as transport molecules and the molecules recognized by the cell membrane receptors), directly enter the cells, including the blood cells [26b]. In addition, the oxidovanadium (IV) cation $\mathrm{VO}^{2+}$ may competitively intervene the $\mathrm{Mg}^{2+}$ transport pathways [27]. In the bone tissue, vanadate is able to partially replace phosphate; $\mathrm{VO}^{2+}$ becomes efficiently incorporated into the hydroxyapatite matrix of the bones, where it is able to make a coordinate bond with triphosphate in the apatite structure of the bone [28a]. In the context of toxic effects and the medicinal applications, vanadate-phosphate antagonism is of particular interest. The anions occurring at physiological conditions are $\mathrm{HPO}_{4}{ }^{2-}$ and $\mathrm{H}_{2} \mathrm{VO}_{4}{ }^{-}$. These anions, although comparable in size, are distinct in their ability to increase their coordination sphere when interacting with the substrates in the physiological broth [28b]. While the vanadium center in vanadate readily increases its coordination environment by establishing a covalent bond with a donor atom $(\mathrm{O}, \mathrm{N}$, or $\mathrm{S})$ of the substrate, usually resulting in the formation of a stable penta-coordinated (distorted) trigonal bipyramid, such a structural arrangement is achieved just intermittently in the case of phosphate.

The medicinal applications of vanadium are rooted either through the in vivo formation of vanadate applied in the form of a coordination compound or in the direct interaction between the coordination center and/or the coordination sphere of the vanadium species applied in a medicinal context. Here, "direct interaction" refers to any of the following: a physiological interference of the original, a physiologically altered coordination compound (as in the case of diabetes, cancer, and cardiac dysrhythmia), or toxicity against the parasites, bacteria, and viruses. So far, not even a single vanadium compound of potential medicinal use has been accredited by the pharmaceutical industry. The only compound to reach the clinical trial phase I and II was the anti-diabetic maltolato-vanadium complex VO (mal) ${ }_{2}$ [29], although it had to be abandoned owing to the associated renal problems with several of the probands. The following subsections would be dealing with the diseases originating from viruses, bacteria, and fungi, as well as with health problems caused by parasites (protozoa, amoebae, and flagellates).

Table 1 provides an overview of the vanadium compounds that have been successfully applied (in vitro and/or in vivo with test animals) in the treatment of selected diseases caused by bacteria, viruses, and parasites. A recent overview concerning the same has been reported previously as well [30]. 
Table 1 Selected vanadium compounds that have been applied in the treatment of diseases caused by viruses, bacteria, and protozoa.

\begin{tabular}{|c|c|c|c|c|}
\hline Disease & $\begin{array}{l}\text { Responsible } \\
\text { Organism }\end{array}$ & Symptoms ${ }^{\text {a) }}$ (selection) & $\begin{array}{l}\text { Compound(s) } \\
\text { in Figure } 4\end{array}$ & Ref. \\
\hline Tuberculosis & $\begin{array}{l}\text { Mycobacterium } \\
\text { tuberculosis }\end{array}$ & $\begin{array}{l}\text { Bloody sputum, chronic } \\
\text { cough }\end{array}$ & 1,2 & $\begin{array}{l}{[31],} \\
{[32]}\end{array}$ \\
\hline $\begin{array}{l}\text { Pneumonia (of } \\
\text { bacterial origin) }\end{array}$ & $\begin{array}{l}\text { Pseudomonas } \\
\text { aeruginosa um) }\end{array}$ & $\begin{array}{l}\text { Cough with phlegm, difficult } \\
\text { breathing, nausea }\end{array}$ & 3 & [33] \\
\hline $\begin{array}{l}\text { Diarrheal } \\
\text { diseases }\end{array}$ & $\begin{array}{l}\text { Giardia } \\
\text { intestinalis (a } \\
\text { protozoa) }\end{array}$ & Diarrhea & $\begin{array}{l}\text { Nicotinamidium } \\
\text { decavanadate }\end{array}$ & [34] \\
\hline AIDS/HIV & $\begin{array}{l}\text { Human } \\
\text { immune } \\
\text { deficiency virus }\end{array}$ & $\begin{array}{l}\text { Failure of the immune } \\
\text { system }\end{array}$ & 4 & {$[35]$} \\
\hline Leishmaniasis & $\begin{array}{l}\text { Leishmania } s p . \\
\text { (a flagellate) }^{\text {b) }}\end{array}$ & $\begin{array}{l}\text { Skin ulcers, anaemia, } \\
\text { damage of spleen and liver }\end{array}$ & 5 & {$[36]$} \\
\hline $\begin{array}{l}\text { Sleeping } \\
\text { sickness }^{c} ; \\
\text { Chagas disease }^{\text {d) }}\end{array}$ & $\begin{array}{l}\text { Trypanosoma } \\
\text { cruzi; T. brucei } \\
\text { (flagellates) }\end{array}$ & $\begin{array}{l}\text { Pains, itching; sensory } \\
\text { disturbance }\end{array}$ & 6 & $\begin{array}{l}{[37],} \\
{[38]}\end{array}$ \\
\hline
\end{tabular}

a) Other than fever. ${ }^{\text {b) }}$ Spread by sand flies. ${ }^{\text {c) }}$ Also known as trypanosomiasis; spread by the Tsetse Fly. ${ }^{\text {d) }}$ Spread by Kissing Bugs.

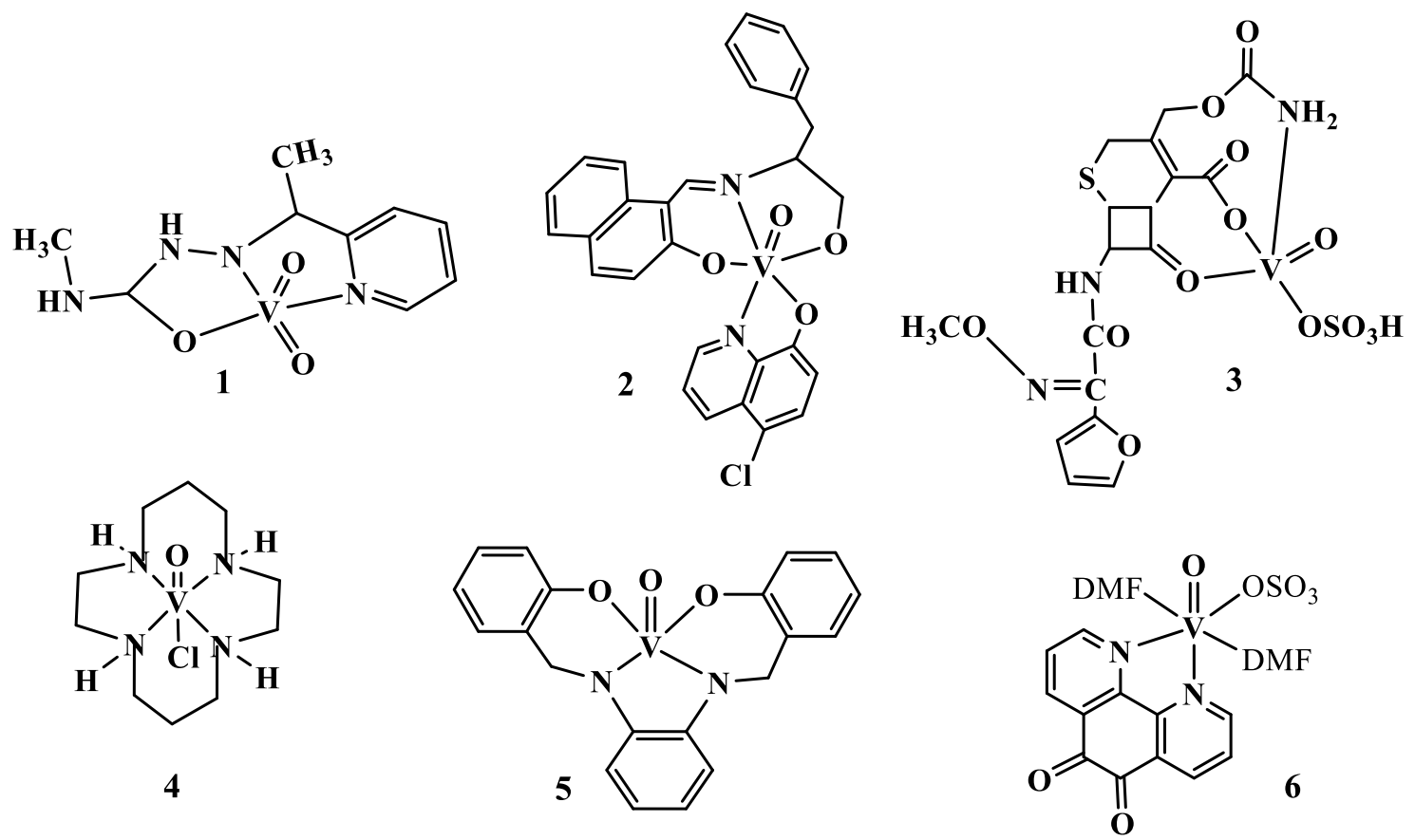

Figure 4 Vanadium complexes that have been shown to be active in the treatment of infectious diseases (cf. Table 1). Ligands: 1, a thiosemicarbazone derivative; 2, salicylglycine + 8-hydroxyquinoline; 3, cefuroxime; 4, cyclam; 5, salophen; 6, phendione. 
Viral replication may also be increased in the presence of vanadium complexes. The anionic compound $\left[\mathrm{VO}_{2} \text { (dipic-Cl) }\right]^{-}$(dipic = dipicolinate), in certain cases such as when applied in combination with the oncolytic (i.e., cancer killing) Rhabdovirus VSVD51, increases viral infection and viability, thereby invigorating the immune system. The initiating compound is probably an intermittently formed vanadate species, which is generated through the hydrolysis of the dipic complex [39]; vanadate on its own, however, is ineffective. In order to have a further general view regarding the nature of the active species, commonly vanadate and/or the ligand and its secondary product(s) that are generated at physiological conditions, refer to the literature [40].

Vanadium compounds have also been successfully evaluated for the treatment of cancer, as reported in a previously published review [41]. Certain recent examples of such compounds have been presented in Figure 5. Complex 1, containing the flavonoid chrysin, has been reported to suppress the growth of osteosarcomas without any side-effects, in xenograft mice bearing a human osteosarcoma cell line [42a], apparently because the product formed as a result of the hydrolytic decomposition and oxidation in the physiological broth, i.e., " $\mathrm{VO}(\mathrm{OH})_{3}$ ", is incorporated into the bone structure (see also, above). In a similar manner, bone cancer was reported to have been treated successfully with Metvan ([VO $\left(\mathrm{Me}_{2}\right.$ phen) $\left.{ }_{2} \mathrm{SO}_{4}\right]$, where phen = phenanthroline and $\mathrm{Me}=\mathrm{CH}_{3}$ ) [42b]. Compound 2 has been reported to exhibit anti-proliferative activity against various cancer cell lines. It binds strongly to the DNA (presumably after the loss of at least one of the ligands), generates reactive oxygen species (peroxide and hyperoxide), and causes damage to the mitochondrial membrane [43]. The target for Compound 3 is the breast cancer cells of MCF-7 ("Michigan cancer foundation") and A549 (pulmonary alveolus). Compound 3 induces apoptosis and inhibits the cell cycles, probably through the generation of intracellular reactive oxygen species, particularly hyperoxide $\mathrm{O}_{2}^{-}[44]$.
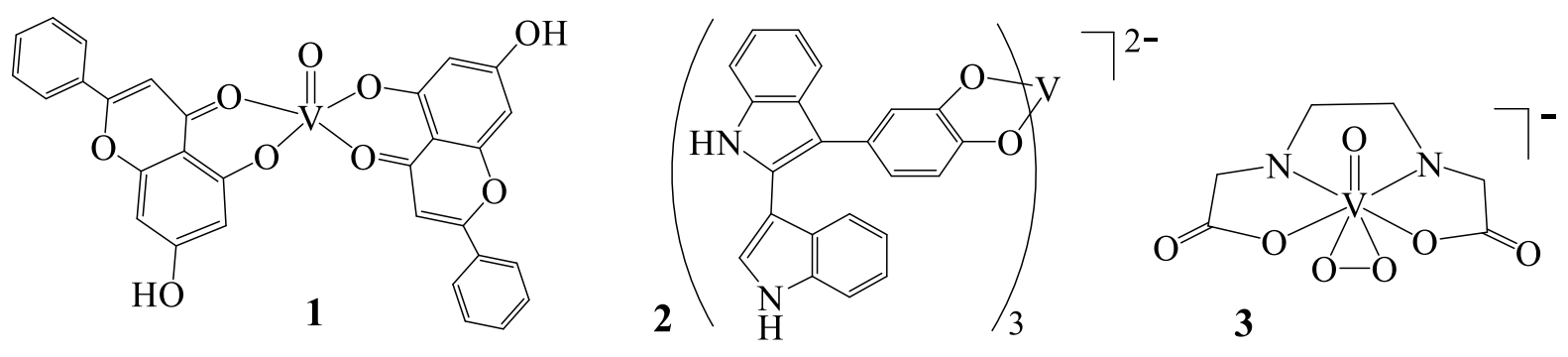

Figure 5 Selected vanadium complexes for the potential treatment of cancer. 1: A chrysin complex for the treatment of osteosarcomas [42a]; 2: a catecholate complex carrying a bis(indolyl) substituent at the catechol moiety, active against various cancer cell lines [43]; 3: a peroxido complex containing an ethylenediamine-diacetate ligand [44].

An additional prominent field in the context of the role of vanadium in health issues is the one concerning diabetes mellitus. As stated earlier, the most significant undertakings in this field concern the clinical tests conducted more than a decade ago, pioneered by Orvig and Thomson [29]. An early report (1899) concerning the usage of vanadate in this regard [45], and the discovery that (i) vanadate as an effective competitor of phosphate in regard to transport, via ATPase, across the cell walls [46a] and that (ii) vanadate inhibits the ribonucleases [46b], served as the crucial basis for the development of vanadium-based compounds for the treatment of 
diabetes (through a decrease in the blood glucose levels). Since then, various vanadium compounds have been introduced (for a recent review, see [47]), a selection of which has been presented in Figure 6. Most of the insulin-mimetic tests have been conducted with streptozotozin (STZ) or alloxan-induced test animals (commonly, rats or mice), and along with a reduction in the blood glucose levels both in the case of diabetes type I and diabetes type II, a lowering of the lipid levels has also been observed. STZ, a nitrosoureido glycopyranose, is toxic for the $b$ cells (responsible for insulin production) located in the Langerhans islets in the pancreas.

A vanadium coordination compound, once applied intravenously, [partially] degrades to form vanadate $\mathrm{H}_{2} \mathrm{VO}_{4}{ }^{-}$, which then enters the cell and binds to the cysteinate residue of the proteintyrosine phosphatase (PTP), thereby inhibiting PTP [48]. This inhibition, in turn, prevents the dephosphorylation of a tyrosine-phosphate residue linked to the intracellular site of the insulin receptor. As a consequence, the receptor is activated and the signaling pathway for glucose uptake is either maintained or restored.<smiles>O=P1(O)OP(=O)(OCC2OC(n3cnc4ccccc43)C(O)C2O)O1</smiles><smiles></smiles><smiles></smiles><smiles></smiles><smiles>O=C1ON(c2cccc(O)c2)S(=O)(=O)OC1=O</smiles>

Figure 6 Some vanadium coordination compounds that have been shown to counteract diabetes mellitus. For compounds 1 to 5, cf. refs. [49] (1), [50] (2), [51] (3), [29b] (4), and [52] (5).

\section{Engineering Aspects}

The application of vanadium for industrial or engineering purposes encompasses three main areas: (1) the vanadium compounds involved in catalysis, (2) vanadium-based batteries, and (3) vanadium in steel production (for example, chromium-vanadium steel, in which the vanadium content is approximately $0.1 \%$, which increases the forgeability of the steel). In regard to the medicinal applications of vanadium (such as the implants with particularly high biocompatibility), the vanadium alloy $\mathrm{Ti}-6 \mathrm{Al}-4 \mathrm{~V}$ having a vanadium content of approximately $4 \%$ is of particular interest [53].

A review concerning the catalytic applications of vanadium was published recently [54]. Vanadium oxides with the general formula of $\mathrm{VO}_{\mathrm{x}}$, where $\mathrm{x}$ ranges from $2\left(\mathrm{~V}^{\mathrm{IV}}, \mathrm{VO}_{2}\right)$ to $2.5\left(\mathrm{~V}^{\mathrm{V}}\right.$, 
$\mathrm{V}_{2} \mathrm{O}_{5}$ ), are employed either directly or along with supports such as clay [55]. A well-documented and industrially applied practical example of this is the generation of sulfuric acid from sulfur dioxide. Also noteworthy is the oxidative conversion of methanol into formaldehyde in the presence of $\mathrm{FeVO}_{4}$ as the catalyst [56a] [eq. (11)]. In the context of the ability of vanadium oxides acting as oxidation catalysts [56b], the antifouling (i.e., destruction [disinfection] through oxidative halogenation) properties of $\mathrm{V}_{2} \mathrm{O}_{5}$ nanowires deserve mention [57]. Low-valent vanadium oxides have been demonstrated to catalyze the hydrogenation of carbon monoxide [58a] and the reduction of nitrogen oxide [58b] [eq. (12) and (13), respectively]. In addition, the vanadiumcatalyzed reduction of $\mathrm{NO}$ is of interest in the context of detoxification of the exhaust gases from automobiles and trucks. Another example of the [potential] importance of vanadium for the biologically relevant [drug] molecules is the enantio-selective oxidation of [aromatic] sulfides/thioethers to form sulfoxides [59]. Silica-supported vanadium oxides, $\mathrm{V}_{\mathrm{x}} \mathrm{O}_{7}-$-silica, have been employed as catalysts in the oxidative detoxification of the remains of organic sulfur compounds, such as dibenzothiophene, present in the crude oil and diesel fuels, through conversion into sulfones, which may be removed with acetonitrile. The oxidant employed in this reaction is $t-\mathrm{BuOOH}[60]$.

$$
\begin{aligned}
& \mathrm{CH}_{3} \mathrm{OH}+1 / 2 \mathrm{O}_{2} \rightarrow \mathrm{HCHO}+\mathrm{H}_{2} \mathrm{O} \text { catalyst: } \mathrm{FeVO}_{4} \\
& \mathrm{CO}+2 \mathrm{H}_{2} \rightarrow \mathrm{CH}_{4}\left(\text { and } \mathrm{C}_{n} \mathrm{H}_{2 n+2}\right)+\mathrm{H}_{2} \mathrm{O} \quad \text { catalyst: } \mathrm{VO}_{x} / \mathrm{Rh} \\
& \mathrm{NO}+\mathrm{CO} \rightarrow \mathrm{HNCO}\left(+\mathrm{NH}_{3}\right) \quad \text { catalyst: } \mathrm{VO}_{x} / \gamma-\mathrm{Al}_{2} \mathrm{O}_{3} / \mathrm{H}_{2} \mathrm{O}
\end{aligned}
$$

Possibly the most prominent example of the employment of vanadium in catalytically conducted processes is its usage in the form of vanadium pentoxide for the production of sulfuric acid [61], the reaction for which is presented in eq. (14).

$$
\mathrm{SO}_{2}+\mathrm{H}_{2} \mathrm{O}+\mathrm{V}_{2} \mathrm{O}_{5} \rightarrow \mathrm{H}_{2} \mathrm{SO}_{4}+\mathrm{V}_{2} \mathrm{O}_{4} ; \mathrm{V}_{2} \mathrm{O}_{4}+\frac{1}{2} \mathrm{O}_{2} \rightarrow \mathrm{V}_{2} \mathrm{O}_{5}
$$

Another application-oriented, and therefore, industrial aspect of the employment of vanadium is its usage in the energy storage/redox-flow batteries [61-63] and in solar cells [64]. Figure 7 presents the examples of (a) a flow battery based on a cathode consisting of lithiumoxidovanadium phosphate $\left(\mathrm{LiVO}\left(\mathrm{PO}_{4}\right)\right)$ and a $\mathrm{VO}_{2}$ anode, (b) a vanadium-only battery, and (c) a dye-sensitized solar cell with a vanadium coordination compound as the electrolyte and the redox mediator ( $\mathrm{VO}^{\mathrm{IV}} \mathrm{L} \leftrightarrows \mathrm{VO}^{\mathrm{V}} \mathrm{L}+\mathrm{e}^{-}$). Principally, the other oxidation states of vanadium (i.e., $\mathrm{V}^{\mathrm{III}}$ and $\mathrm{V}^{\mathrm{II}}$ ) could also play a role in vanadium-based batteries, thereby providing high energy densities, and may also be utilized in the storage batteries where the electron flow between $\mathrm{V}^{2+/ 3+}$ and/or $\mathrm{VO}^{2+/ 3+}$ is deployed. 

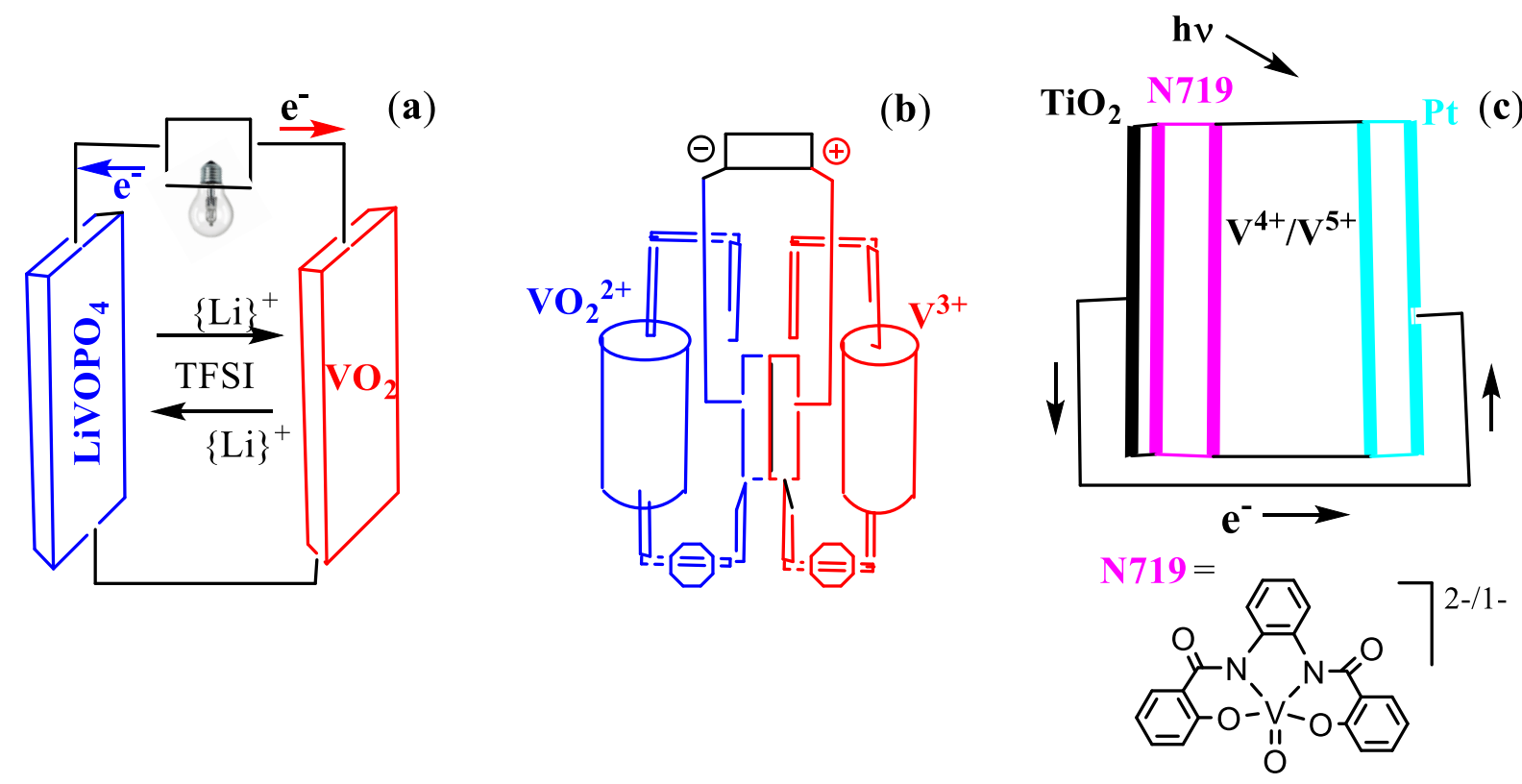

Figure 7 (a) and (b): Schematic views of a lithium-vanadium (left) [61] and a vanadiumonly battery (centre); red = catholite, blue = anolyte. (c): A dye-sensitized solar cell based on $\mathrm{V}^{\mathrm{IV} / \mathrm{V}} \mathrm{OL}[64] ; \mathrm{L}$ is the diamidodiphenolato ligand $\mathrm{TFSI}=\left[\mathrm{F}_{3} \mathrm{C}-\mathrm{SO}_{2}-\mathrm{N}-\mathrm{SO}_{2}-\mathrm{CF}_{3}\right]^{-}$ coordinated to $\mathrm{Li}^{+}$.

\section{Author Contributions}

Dr. Dieter Rehder did all the work.

\section{Competing Interests}

The author has declared that no competing interests exist.

\section{References}

1. (a) Wang D, Wilhelmy AS. Vanadium speciation and cycling in coastal waters. Mar Chem. 2009; 117: 52-58. (b) Wright MT, Berlitz K. Factors controlling the regional distribution of vanadium in ground water. Ground Water. 2010; 48: 515-525. (c) Huang JH, Huang F, Evans L, Glasauer S. Vanadium: Global (bio)geochemistry. Chem Geol. 2015; 417: 68-89.

2. (a) Rehder D. Vanadium. Ref Mod Chem Mol Sci Chem Engin 2016; 1-11. (b) Costa Pessoa J, Etcheverry S, Gambino D. Vanadium Compounds in Medicine. Coord Chem Rev. 2015; 301: 24-48. (c) Crans DC, Smee JJ, Gaidamauskas E, Yang L. The chemistry and biochemistry of vanadium and its biological activities excerted by vanadium compounds. Chem Rev. 2004; 104: 849-902.

3. Gustafsson JP. Vanadium geochemistry in the biogeosphere - Speciation, solid-solution interactions, and ecotoxicity. Appl Geochem. 2019; 102: 1-25

4. Crans DC, Henry L, Cardiff G, Posner BI. Developing vanadium as an antidiabetic or anticancer drug: A clinical and historical perspective. Met lons Life Sci. 2019; 19: 203-230.

5. Rehder D. Vanadate-dependent peroxidases in macroalgae: Function, applications, and environmental impact. Oceanography. 2014; 2: 121. doi:10.4172/2332-2632.1000121. 
6. Leblanc C, Vilter H, Fournier JB, Delage L, Potin P, Rebuffet E, et al. Vanadium haloperoxidases: from the discovery 30 years ago to $\mathrm{X}$-ray crystallographic and $\mathrm{V}$ K-edge absorption spectroscopic studies. Coord Chem Rev. 2015; 301: 134-146.

7. Wever R, Krenn BE, Renirie R. Marine vanadium-dependent haloperoxidases, their isolation, characterization, and application. Methods Enzymol. 2018; 605: 141-200.

8. Messerschmidt A, Prade L, Wever R. Implications for the catalytic mechanism of the vanadium-containing enzyme chloroperoxidase from the fungus Curvularia inaequalis by X-ray structures of the native and peroxide form. Biol Chem. 1997; 378: 309-316.

9. Vilter H. Peroxidases from Phaeophyceae: A vanadium(V)-dependent peroxidase from Ascophyllum nodosum. Phytochem. 1984; 23: 1387-1390.

10. Rebelein JG, Lee CC, Newcomb M, Hu Y, Ribbe MW. Characterization of an M-clustersubstituted nitrogenase VFe protein. mBio. 2018; 9: 1-8.

11. Sickermann NS, $\mathrm{Hu}$ Y, Ribbe MW. Activatiuon of $\mathrm{CO}_{2}$ by vvanadium nitrogenase. Chem Asian J. 2017; 12: 1985-1996.

12. Fischer K, Dilworth MJ, Newton WE. Azotobacter vinelandii vanadium nitrogenase: Formaldehyde is a product of catalyzed HCN reduction, and excess ammonia arises directly from catalyzed azide reduction. Biochem. 2006; 45: 4190-4198.

13. Benediktsson $B$, Thorhallsson AT, Bjornsson R. QM/MM calculations reveal a bridging hydroxo group in a vanadium nitrogenase crystal structure. Chem Comm. 2018; 54: 7310-7313.

14. Yamaguchi N, Yoshinaga M, Kamino K, Ueki T. Vanadium-binding ability of nucleoside diphosphate kinase from the vanadium-rich fan worm Psedopotamilla occelata. Zool Sci. 2016; 33: 266-271.

15. (a) Hamada T, Asanuma M, Ueki T, Hayashi F, Kobayashi N. Solution structure of vanabin2, a vanadium(IV) binding protein from the vanadium-rich Ascidian Ascidia sydneidensis samea. J Am Chem Soc. 2005; 127: 4216-4222. (b) Antipov AN, Lyalikova NN, L'vov NP. Vanadiumbinding protein excreted by vanadate-reducing bacteria._IUBMB Life. 2000; 49: 137-141.

16. Csotnyi JT, Stackebrandt E, Yurkov V. Anaerobic respiration of tellurate and other metalloids in bacteria from hydrothermal vent fields in the Eastern Pacific Ocean. Appl Environ Microbiol. 2006; 72: 4945-4956.

17. Antipov AN. Vanadium in Life Organisms. In: Kretsinger RH, Uversky VN, Permyakov EA (eds). Enzyclopedia of Metalloproteins. Springer. 2013; New York, NY.

18. Carpentier W, De Smet L, Van Beeumen J, Brigé A. Respiration and Growth of Shewanella oneidensis MR-1 Using Vanadate as the Sole Electron Acceptor. J Bacteriol. 2005; 187: 32933301.

19. Wang G, Zhang B, Li S, Yang M, Yin C. Simultaneous microbial reduction of vanadium(V) and chromium (VI) by Shewanella loihica PV-4. Biores Technol. 2017; 227: 353-358.

20. Mohamed EAH. Biophysical remediation of vanadium by Shewanella sp. E1. Ind J Biotechnol. 2017; 16: 380-386.

21. Ortiz-Bernad I, Anderson RT, Vrionis HA, Lovely DR. Vanadium respiration by Geobacter metallireducens: novel strategy for in situ removal of vanadium from groundwater. Appl Environ Microbiol. 2004; 70: 1405-1412. 
22. (a) Carpentier W, De Smet L,Van Beeumen J, Brigé A. Respiration and growth of Shewanella oneidensis MR-1 using vanadate as the sole electron acceptor. J Bacteriol. 2005; 187: 32933301. (b) Carpentier W, PhD thesis, University of Gent. 2005.

23. Li D, Cheng YY, Wu C, Li WW, Li N, Yang ZC, et al. Selenite reduction by Shewanella oneidensis MR-1 is mediated by fumarate reductase in periplasm. Sci Rep. 2014; 4: 3735.

24. Ortiz-Bernad I, Anderson RT, Vrionis HA, Loveley DR. Vanadium respiration by Geobacter metallireducens: Novel strategy for In situ removal of vanadium from groundwater. Appl Environ Microbiol. 2004; 70: 3091-3095.

25. Xu X, Xia S, Zhou L, Zhang Z, Rittmann B. Bioreduction of vanadium(V) in groundwater by autohydrogenotrophic bacteria: Mechanism and microorganisms. J Environ Sci. 2015; 30: 122-128.

26. (a) Levina A, McLeod Al, Gasparim SJ, Nguyen A, De Silva WGM, Aitken JB, et al. Reactivity and speciation of anti-diabetic vanadium complexes in whole blood and its components: The important role of red blood cells. Inorg Chem. 2015; 54: 7763-7766. (b) Liboiron BD, Thompson KH, Hanson GR, Lam E, Aebischer M, Orvig C. New insights into the interactions of serum proteins with bis(maltolato)oxovanadium(IV): Transport and biotransformation of insulin-enhancing vanadium pharmaceuticals. J Am Chem Soc. 2005; 127:5104-5115. (c) Sanna D, Palomba J, Lubino G, BuglyóP, Nagy S, Perdih F, et al. Role of ligands in the uptake and reduction of $\mathrm{V}(\mathrm{V})$ complexes in red blood cells. J Med Chem. 2019; 63: 654-664.

27. Ścibior A. Vanadium (V) and magnesium (Mg) - In vivo interactions: A review. Chem Biol Interact. 2016; 258: 214-233.

28. (a) Dikanov SA, Liboiron BD, Orvig C. Two-dimensional (2D) pulsed electron paramagnetic resonance study of $\mathrm{VO}^{2+}$-triphosphate interactions: Evidence for tridentate triphosphate coordination, and relevance to bone uptake and insulin enhancement by vanadium pharmaceuticals. J Am Chem Soc. 2002; 124: 2969-2978. (b) Pessoa JC, Garribba E, Santos MFA, Santos Silva T. Vanadium and proteins: Uptake, transport, structure, activity and function. Coord Chem Rev. 2015; 301-302: 49-86.

29. (a) Thompson $\mathrm{KH}$, Orvig C. Vanadium in diabetes: 100 years from Phase 0 to Phase I. J Inorg Biochem. 2006; 100: 1925-1935. (b) Thompson KH, Lichter J, LeBel C, Scaife MC, McNeill JH, Orvig C. Vanadium treatment of type 2 diabetes: A view to the future. J Inorg Biochem. 2009; 103: 554-558.

30. Rehder D. Perspectives for vanadium in health issues. Fut Med Chem. 2016; 8: 325-338.

31. Maia PI da S, Pavan FR, Leite CQF, Lemos SS, deSousa GF, Batista AA et al. Vanadium complexes with thiosemicarbazones: Synthesis, characterization, crystal structures and antiMycobacterium tuberculosis activity. Polyhedron. 2009; 28: 398-406.

32. Correia I, Adão P, Roy S, Wahba M, Matos C, Maurya MR et al. Hydroxyquinoline derived vanadium(IV and V) and copper(II) complexes as potential anti-tuberculosis and anti-tumor agents. J Inorg Biochem. 2014; 141: 83-93.

33. (a) Datta C, Das D, Mondal P, Chakraborty B, Sengupta M, Bhattacharjee CR. Novel water soluble neutral vanadium(IV)-antibiotic complex: Antioxidant, immunomodulatory and molecular docking studies. J Med Chem. 2015; 97: 214-224. (b) Tsave O, Petanidis S, Kioseoglou E, Yavropoulou MP, Vovos JG, Anestakis D et al. Role of vanadium in cellular and molecular immunology: Association with immune-related inflammation and pharmacotoxicology mechanism. Oxid Med Cell Longev. 2016; 2016: 10. 
34. Missina JM, Gavinho B, Postal K, Santana FS, Valdameri G, de Souza EM et al. Effects of decavanadate salts with organic and inorganic cations on Escherichia coli and Giardia intestinalis, and vero cells. Inorg Chem. 2018; 57: 11930-11941.

35. Ross A, Soares DC, Covelli D, Pannecouque C, Budd L, Collins A, et al. Oxovanadium(IV) cyclam and bicyclam complexes: Potential CXCR4 receptor antagonists. Inorg Chem. 2010; 49: 11221132.

36. de Almeida Machado M, Mota VZ, de Lima Cavalli AC, Gonçalves de Carvalho GS, Da Silva AD, Gameiro J, et al. High selective antileishmanial activity of vanadium complex with stilbene derivative. Acta Trop. 2015; 148: 120-127.

37. Fernández M, Becco L, Correia I, Benítez J, Piro OE, Echeverria GA, et al. Oxidovanadium(IV) and dioxidovanadium(V) complexes of tridentate salicylaldehyde semicarbazones: Searching for prospective antitrypanosomal agents. J Inorg Biochem. 2013; 127: 150-160.

38. Benítez J, Correiea I, Becco L, Fernández M, Garat B, Gallordo H, et al. Searching for vanadium-based prospective agents against trypanosoma cruzi: Oxidovanadium(IV) compounds with phenanthroline derivatives as ligands. Z Anorg Allgem Chem. 2013; 639: 1417-1425.

39. Bergeron A, Kostenkova K, Selman M, Murakami HA, Owens E, Haribabu N, et al. Enhancement of oncolytic virotherapy by vanadium(V) dipicolinates. Biometals. 2019; 32: 545-561.

40. Levina A, Lay PA. Stabilities and biological activities of vanadium drugs: What is the nature of the active species? Chem Asian J. 2017; 12: 1692-1699.

41. Kioseoglou E, Petanidis S, Gabriel C, Salifoglou A. The chemistry and biology of vanadium compounds in cancer therapeutics. Coord Chem Rev. 2015; 301-302: 87-105.

42. (a) León IE, Cadavid-Vargas JE, Resasco A, Maschi F, Ayala MA, Carbone C, et al. In vitro and in vivo antitumor effect of the VO-chrysine complex on a new three-dimensional osteosarcoma spheroids model and a xenograft tumor in mice. J Biol Inorg Chem. 2016; 21: 1009-1029. (b) Cacicedo ML, Ruiz MC, Scioli-Montoto S, Ruiz ME, Fernándeu MA, TorresSanchez RM, et al. Lipid nanoparticles - Metvan: revealing a novel way to deliver a vanadium compound to bone cancer cells. New J Chem. 2019; 43: 17726-17734.

43. Dankhoff K, Ahmad A, Weber B, Biersack B, Schobert R. Anticancer properties of a new vanadium(IV) complex with catechol-modified 3,3'-diindolylmethane ligand. J Inorg Biochem. 2019; 194:1-6.

44. Chen F, Gao Z, You C, Wu H, Li Y, He X. Three peroxidovanadium(V) compounds mediated by transition metal cations for enhanced anticancer activity. Dalton Trans. 2019; 48: 1516015169.

45. Lyonnet B, Martz M, Martin E. L'emploi Therapeutique de Dérivés du vanadium. La Press Médical. 1899; 32: 191-192.

46. (a) Cantley LC, Resh MD, Guidotti G. Vanadate inhibits the red cell $\left(\mathrm{Na}^{+}, \mathrm{K}^{+}\right)$ATPase from the cytoplasmic side. Nature. 1978; 272: 552-554. (b) Berger SL, Birkenmeier CS. Inhibition of intractable nucleases with ribo- nucleoside-vanadyl complexes: isolation of messenger ribonucleic acid from resting lymphocytes. Biochem. 1978; 18: 5143-5149.

47. Crans DC, Henry L, Cardiff G, Posner BI. Developing vanadium as an antidiabetic drug: A clinical and historical perspective. Met lons Life Sci. 2019; 19: 203-230.

48. Irving E, Stoker AW. Vanadium compounds as PTP inhibitors. Molecules. 2017; 22: 2269-2288. 
49. Naglah AM, Al-Omar MA, Bhat MA, Al-Wasidi AS, Alsuhaibani AMA, El-Didamony AM, et al. Synthesis and biological evaluation of a novel oxidovanadium(IV) adenosine monophosphate complex as anti-diabetic agent. Crystals. 2019; 9, 208: 1-13.

50. Naglah AM, Al-Omar MA, Almehizia AA, Bhat MA, Afifi WM, Al-Wasidi AS, et al. A novel oxidovanadium (IV)-orotate complex as an alternative antidiabetic agent: Synthesis, characterization, and biological assessments. BioMed Res Int. 2018: 1-11.

51. Gätjens J, Meier B, Adachi Y, Sakurai H, Rehder D. Characterization and insulin-mimetic potential of oxidovanadium(IV) complexes derived from monoesters and carboxylates of 2,5dipicolinic acid. Eur J Inorg Chem. 2006: 3575-3585.

52. Koleša-Dobravec T, Maejima K, Yoshikawa Y, Meden A, Yasui H, Perdih F. Bis(picolinato) complexes of vanadium and zinc as potential antidiabetic agents: synthesis, structural elucidation and in vitro insulin-mimetic activity study. New J Chem. 2018; 42: 3619.

53. Murr LE, Esquivel EV, Quinones SA, Gaytan SM, Lopez MI, Martinez EY, et al. Microstructures and mechanical properties of electron beam-rapid manufactured Ti-6Al-4V biomedical prototypes compared to wrought Ti-6Al-4V. Mater Charact. 2009; 60: 96-105.

54. (a) Langeslay RR, Kaphan DM, Marshall CL, Stair PC, Sattelberger AP, et al. Catalytic applications of vanadium: A mechanistic perspective. Chem Rev. 2019; 119: 2128-2192. (b) Sutradhar M, Martins LMDRS, Guedes da Silva, MFC, Pombeiro AJL. Vanadium complexes: Recent progress in oxidation catalysis. Coord Chem Rev. 2015; 301-302: 200-239.

55. Shul'pina LS, Kirillova MV, Pombeiro AJL, Shul'pin GB. Alkane oxidation by the $\mathrm{H}_{2} \mathrm{O}_{2}-\mathrm{NaVO}_{3}-$ $\mathrm{H}_{2} \mathrm{SO}_{4}$ system in acetonitrile and water. Tetrahedron. 2009; 65: 2424-2429,

56. (a) Stepovik L, Potkina AY. Oxidation of alkylarene $\mathrm{C}-\mathrm{H}$ bonds by tert-butyl hydroperoxide in the presence of cobalt, chromium, and vanadium acetylacetonates. Russ J Gen Chem. 2013; 83: 1047-1059. (b) Sutradhar M, Martins LMDRS, da Silva MFCG, Pombeiro AJL. Vanadium complexes: Recent progress in oxidation catalysis. Coord Chem Rev. 2015; 301-302: 200-239.

57. André $\mathrm{R}$, Natálio $\mathrm{F}$, Humanes $\mathrm{M}$, Leppin J, Heinze $\mathrm{K}$, Wever $\mathrm{R}$, et al. $\mathrm{V}_{2} \mathrm{O}_{5}$ nanowires with an intrinsic peroxidase-like activity. Adv Funct Mater. 2011; 21: 501-509.

58. (a) Jenewein B, Penner S, Hayek, K. Structure-activity correlation in thin film model catalysts: $\mathrm{CO}$ hydrogenation on $\mathrm{Rh} / \mathrm{VO}_{\mathrm{x}}$ : Part II. Catalytic activity as a function of oxidation and reduction. Appl Catal A. 2006; 308: 43-49. (b) Neyertz C, Volpe M, Perez D, Costilla I, Sanchez $\mathrm{M}$, Gigola S. NO reduction with $\mathrm{CO}$ in the presence and absence of $\mathrm{H}_{2} \mathrm{O}$ over $\mathrm{Pd} / \mathrm{Y}-\mathrm{Al}_{2} \mathrm{O}_{3}$ and $\mathrm{Pd}-\mathrm{VO}_{x} / \mathrm{Y}-\mathrm{Al}_{2} \mathrm{O}_{3}$ catalysts: The formation of $\mathrm{HNCO}, \mathrm{NH}_{3}$ and stable surface species. Appl Catal A. 2009; 368: 146-157.

59. Conte V, Coletti A, Floris B, Licini G, Zonta C. Mechanistic aspects of vanadium catalysed oxidations with peroxides. Coord Chem Rev. 2011; 255: 2165-2177.

60. Dembaremba TO, van Der Westhuizen R, Welthagen W, Ferg E, Ogunlaja AS, Tshentu ZR. Comparing the catalytic activity of silica-supported vanadium oxides and the polymer nanofiber-supported oxidovanadium(IV) complex toward oxidation of refractory organosulfur compounds in hydrotreated diesel. Energy Fuels. 2019; 33, 8: 7595-7603.

61. (a) Shao M, Deng J, Zhong F, Cao Y, Ai X, Quian J, et al. An all-vanadium aqueous lithium ion battery with high energy density and long lifespan. Energ Stor Mat. 2019; 18: 92-99. (b) Qi Z, Koenig GM. Flow battery systems with solid electroactive materials. J Vacuum Sci Technol B: Nanotechnol Microelectr Mat. 2017; 35: 040801. 
62. Xiong $X$, Wang $\mathrm{Z}$, Li X, Guo H. Study on ultrafast synthesis of $\mathrm{LiV}_{3} \mathrm{O}_{8}$ cathode material for lithium-ion batteries. Mater Lett. 2012; 76: 8-10.

63. Takeuchi E, Marshilok AC, Tanzil K, Kozarski ES, Zhu Z, Takeuchi KJ. Electrochemical reduction of silver vanadium phosphorous oxide, $\mathrm{Ag}_{2} \mathrm{VO}_{2} \mathrm{PO}_{4}$ : the formation of electrically conductive metallic silver nanoparticles. Chem Mater. 2009; 21: 4934-4939.

64. Apostolopoulou A, Vlasiou M, Tziouris PA, Tsiafoulis C, Tsipis AC, Rehder D, et al. Oxidovanadium(IV/V) complexes as new redox mediators in dye-sensitized solar cells: $A$ combined experimental and theoretical study. Inorg Chem. 2015; 54: 3979-3988.

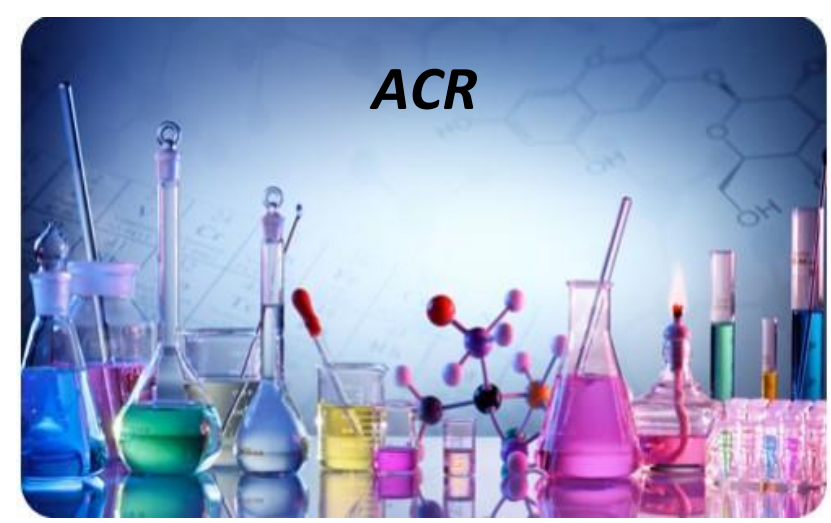

Enjoy $A C R$ by:

1. Submitting a manuscript

2. Joining in volunteer reviewer bank

3. Joining Editorial Board

4. Guest editing a special issue

For more details, please visit:

http://www.lidsen.com/journals/acr 